\title{
Effects of photobiomodulation on the growth of intestinal bacteria
}

\author{
Efeitos da fotobiomodulação no crescimento de bactérias intestinais \\ Efectos de la fotobiomodulación sobre el crecimiento de bacterias intestinales
}

Received: 06/11/2021 | Reviewed: 06/27/2021 | Accept: 07/08/2021 | Published: 07/18/2021

\author{
Carolina Supino \\ ORCID: https://orcid.org/0000-0002-2185-9055 \\ Universidade do Vale do Paraíba, Brazil \\ E-mail: carolsupino@yahoo.com.br \\ Cristina Pacheco-Soares \\ ORCID: https://orcid.org/0000-0002-0572-074X \\ Universidade do Vale do Paraíba, Brazil \\ E-mail: cpsoares@univap.br \\ Newton Soares da Silva \\ ORCID: https://orcid.org/0000-0001-6452-9278 \\ Universidade do Vale do Paraíba, Brazil \\ E-mail: nsoares@univap.br
}

\begin{abstract}
Necrotizing enterocolitis is an inflammatory bowel disease that occurs in newborns, more commonly in preterm infants. It is the leading cause of death from gastrointestinal diseases in neonates, and is characterized by the development of diffuse intestinal necrosis in premature infants subjected to stress. The high incidence and lack of effective treatment strategies suggest that new approaches to treating the disease are needed. It is in this context that the possibility of using photobiomodulation as a therapeutic modality arises. However, studies on the use of photobiomodulation in intestinal bacteria are scarce. To study the effect of photobiomodulation used in clinical parameters on the growth of bacteria commonly present in the newborn microbiota. Four strains of bacteria were chosen to be studied, two belonging to healthy intestinal microbiota, Lactobacillus acidophilus and Lactobacillus reuteri, and two pathogenic bacteria, Escherichia coli and Staphylococcus aureus. These bacteria were cultivated in planktonic growth and irradiated with LED at a wavelength of $660 \mathrm{~nm}$ and a power density of $0.025 \mathrm{~W} / \mathrm{cm}^{2}$, at fluences of 1,5 and $10 \mathrm{~J} / \mathrm{cm}^{2}$. The evaluation of cell growth was performed through absorbance readings in the periods of $4 \mathrm{~h}, 24 \mathrm{~h}$ and $48 \mathrm{~h}$ after irradiation. The growth of $L$. acidophilus, $L$. reuteri and $S$. aureus did not undergo biomodulation in any of the fluences. The growth of $E$. coli was stimulated at $1 \mathrm{~J} / \mathrm{cm}^{2}$ when compared to the Control group, with statistical significance $(\mathrm{p}<0.005)$. In the other fluencies there was no biostimulation for the $E$. coli bacteria. The use of a wavelength of $660 \mathrm{~nm}$ in the fluences of $5 \mathrm{~J} / \mathrm{cm}^{2}$ and $10 \mathrm{~J} / \mathrm{cm}^{2}$ in the studied bacteria did not lead to a significant change in the growth rate.
\end{abstract}

Keywords: Necrotizing enterocolitis; Photobiomodulation; Intestinal bacteria.

\section{Resumo}

A enterocolite necrotizante é uma doença inflamatória intestinal que ocorre no récem-nascido, mais comumente no prematuro. É a principal causa de morte por doenças gastrointestinais em neonatos, e caracterizada pelo desenvolvimento de necrose intestinal difusa no prematuro submetido a estresse. A alta incidência e a falta de estratégias de tratamentos efetivas sugerem que novas abordagens para o tratamento da doença são necessárias. É neste contexto que surge a possibilidade do uso da fotobiomodulação como modalidade terapêutica. Porém, os estudos sobre a utilização da fotobiomodulação em bactérias intestinais são escassos. Estudar o efeito da fotobiomodulação utilizado em parâmetros clínicos no crescimento de bactérias comumente presentes na microbiota do recém nascido. Foram escolhidos 4 cepas de bactérias para serem estudadas, sendo duas pertencentes a microbiota intestinal saudável, Lactobacillus acidophilus e Lactobacillus reuteri e duas bactérias patogênicas, Escherichia coli e Staphylococcus aureus. Essas bactérias foram cultivadas em crescimento planctônico e irradiadas com LED em comprimento de onda $660 \mathrm{~nm}$ e uma densidade de potência de $0,025 \mathrm{~W} / \mathrm{cm}^{2}$, em fluências de 1,5 e $10 \mathrm{~J} / \mathrm{cm}^{2}$. A avaliação do crescimento celular foi realizada através de leituras por absorvância nos períodos de $4 \mathrm{~h}, 24 \mathrm{~h}$ e $48 \mathrm{~h}$ após irradiação. O crescimento de $L$. acidophilus, $L$. reuteri e $S$. aureus não sofreu biomodulação em nenhuma das fluências. O crescimento de $E$. coli foi estimulado em $1 \mathrm{~J} / \mathrm{cm}^{2}$ quando comparado ao grupo Controle, com significância estatística $(\mathrm{p}<0,005)$. Nas demais fluências não houve bioestimulação para a bactéria E.coli. O uso do comprimento de onda de $660 \mathrm{~nm}$ nas fluências de $5 \mathrm{~J} / \mathrm{cm}^{2}$ e $10 \mathrm{~J} / \mathrm{cm}^{2}$ nas bactérias estudadas não levou a uma alteração na velocidade de crescimento significativo.

Palavras-chave: Enterocolite necrotizante; Fotobiomodulação; Bactérias intestinais. 


\section{Resumen}

La enterocolitis necrotizante es una enfermedad inflamatoria intestinal que se presenta en recién nacidos, más comúnmente en bebés prematuros. Es la principal causa de muerte por enfermedades gastrointestinales en recién nacidos y se caracteriza por el desarrollo de necrosis intestinal difusa en bebés prematuros sometidos a estrés. La alta incidencia y la falta de estrategias de tratamiento efectivas sugieren que se necesitan nuevos enfoques para tratar la enfermedad. Es en este contexto que surge la posibilidad de utilizar la fotobiomodulación como modalidad terapéutica. Sin embargo, los estudios sobre el uso de la fotobiomodulación en bacterias intestinales son escasos. Estudiar el efecto de la fotobiomodulación utilizada en parámetros clínicos sobre el crecimiento de bacterias comúnmente presentes en la microbiota neonatal. Se eligieron cuatro cepas de bacterias para su estudio, dos pertenecientes a la microbiota intestinal sana, Lactobacillus acidophilus y Lactobacillus reuteri, y dos bacterias patógenas, Escherichia coli y Staphylococcus aureus. Estas bacterias se cultivaron en crecimiento planctónico y se irradiaron con LED a una longitud de onda de $660 \mathrm{~nm}$ y una densidad de potencia de $0,025 \mathrm{~W} / \mathrm{cm}^{2}$, a fluencias de 1,5 y $10 \mathrm{~J} / \mathrm{cm}^{2}$. La evaluación del crecimiento celular se realizó mediante lecturas de absorbancia en los periodos de $4 \mathrm{~h}$, $24 \mathrm{~h}$ y $48 \mathrm{~h}$ posteriores a la irradiación. El crecimiento de L. acidophilus, L. reuteri y S. aureus no experimentó biomodulación en ninguno de los flujos. El crecimiento de $E$. coli se estimuló a $1 \mathrm{~J} / \mathrm{cm}^{2}$ en comparación con el grupo Control, con significación estadística (p <0,005). En las otras fluencias no hubo bioestimulación para la bacteria $E$. coli. El uso de una longitud de onda de $660 \mathrm{~nm}$ en las fluencias de $5 \mathrm{~J} / \mathrm{cm}^{2}$ y $10 \mathrm{~J} / \mathrm{cm}^{2}$ en las bacterias estudiadas no produjo un cambio significativo en la tasa de crecimiento.

Palabras clave: Enterocolitis necrotizante; Fotobiomodulación; Bacterias intestinales.

\section{Introduction}

Necrotizing enterocolitis (NEC) is an inflammatory bowel disease that occurs in the newborn, more commonly in the premature infant, with a high mortality and morbidity rate. It has been one of the most difficult diseases to eradicate and has become a priority for research. The mortality rate varies from 20 to $30 \%$. The intense inflammatory process that begins in the highly immunoreactive intestine extends the disease systemically, affecting other organs, such as the brain. Despite many studies, prevention strategies do not present a satisfactory result, showing the lack of clear definitions of what constitutes the diagnosis of classic NEC (Obladen, 2009).

The pathophysiology of the disease is not fully understood. Epidemiological observations suggest that it is a multifactorial disease. The condition is probably related to the newborn's gastrointestinal tract's immaturity, which facilitates the multiplication of pathogenic bacteria and their translocation. It happens through mixed colonization of the child's intestine, and pathogens frequently found are Staphylococcus aureus and Escherichia coli. Treatment consists of antibiotic therapy and fasting. The condition is associated with an intense inflammatory process and mesenteric vasoconstriction, leading to a state of intestinal ischemia and necrosis with extremely short and long-term sequelae (Sueh et al., 2002; Samuels et al., 2017).

Photobiomodulation by light in the red to the spectrum's infrared region $(630-1000 \mathrm{~nm})$ modulates numerous cellular functions. The clinical and experimental applications of photobiomodulation have expanded over the past 30 years. Low-power lasers and light-emitting diodes (LEDs) are well-accepted therapeutic tools for treating infected, ischemic, and hypoxic wounds and other soft tissue injuries. The positive effects of photobiomodulation include accelerated healing, better recovery from ischemic lesions in the heart, and attenuated degeneration of the injured optic nerve (Desmet et al., 2006). At the cellular level, photobiomodulation can modulate fibroblasts' proliferation, the fixation and synthesis of collagen and procollagen, promote angiogenesis and stimulate macrophages and lymphocytes, improving energy metabolism in mitochondria. Besides, photobiomodulation has demonstrated the ability to increase the production of growth factors, such as keratinocyte growth factor (KGF), transforming growth factor (TGF), and platelet-derived growth factor (PDGF) (Desmet et al., 2006; Hamblin, 2017).

The advances in the clinical use of photobiomodulation and its anti-inflammatory, neovascularization, and cell regeneration effects, transform this therapeutic modality into an excellent option for the treatment of this pathology, being noninvasive and easy to apply (Desmet et al., 2006). The possibility of a new therapeutic modality, without side effects, reducing antibiotic therapy time, the need for surgical intervention, decreased use of antibiotic therapy, parenteral nutrition, and shorter 
hospital stay is very positive in treating these children. The prospect of a satisfactory biomodulation response in this disease could revolutionize the treatment and survival of premature babies and the quality of life of these children in the future.

The limiting factor at the moment for the use of laser therapy in intestinal pathologies is the potential biostimulating effect on intestinal bacteria, which would make its use unfeasible. Both an increase in pathogenic bacteria and a massive increase in flora bacteria in immunocompromised patients is not tolerable. The number of photobiomodulation studies in intestinal pathologies is scarce, but with a potential for promising clinical application. In in vitro studies on the influence of photobiomodulation on bacterial growth, the results are diverse. Depending on the dose and parameters used, bacterial growth can be stimulated or inhibited, varying with bacteria species (Nussbaum et al., 2003).

In order to study the effect of photobiomodulation on the growth of some bacteria that colonize the newborn's intestine, we conducted this study.

\section{Methodology}

That experimental study, in vitro, used a deductive hypothetical method, with a quantitative approach through statistical analysis of the collected data (Pereira et al., 2018).

Four species of bacteria were selected to be studied. Two belonging to healthy intestinal flora (Lactobacillus acidophilus and Lactobacillus reuteri) and two pathogenic bacteria that commonly infect newborns' intestines (Escherichia coli and Staphylococcus aureus). Strains of Staphylococcus aureus ATCC 25923, Escherichia coli ATCC 25922, grown in BHI medium, and Lactobacillus reuteri DSM17938, Lactobacillus acidophilus LA14, grown in MRS medium were used to carry out the research. After bacterial growth in 24 hours, the cells were added to a culture plate and irradiated by the Irrad LED 5660 Biopdi equipment (São Carlos Brasil) with diodes at $660 \mathrm{~nm}$ wavelengths and a power of $0.025 \mathrm{~W} / \mathrm{cm}^{2}$, in doses of 1,5 and $10 \mathrm{~J} / \mathrm{cm}^{2}$ for 40 seconds, 3 minutes 20 seconds and 6 minutes and 40 seconds, respectively. The readings were taken at 4h, 24h, and 48h.

In each experiment, four groups were prepared: initial reading, control, $1 \mathrm{~J} / \mathrm{cm}^{2}, 5 \mathrm{~J} / \mathrm{cm}^{2}$, and $10 \mathrm{~J} / \mathrm{cm}^{2}$, and four experiments were repeated. The initial number of bacteria was read by optical spectrophotometry, using the SpectraCount ${ }^{\circledR}$ Spectrophotometer (Packard) with a 570nm filter to measure the optical density of bacterial suspensions (Aacos et al., 2004 ).

\section{Results}

The growth of L. acidophilus (Table1) and L. reuteri (Table 2) did not undergo biomodulation in any of the fluences.

Table 1 - Average and standard deviation of the colony-forming units x $10^{8}$ of Lactobacillus acidophilus in the control and irradiated groups at $660 \mathrm{~nm}$ wavelength, with fluences 1,5 , and $10 \mathrm{~J} / \mathrm{cm}^{2}$

\begin{tabular}{|ccccc|}
\hline & $\begin{array}{c}\text { Control } \\
\mathbf{n = 2 4}\end{array}$ & $\begin{array}{c}\mathbf{1 J} / \mathbf{c m}^{\mathbf{2}} \\
\mathbf{n = 2 3}\end{array}$ & $\begin{array}{c}\mathbf{5 J} / \mathbf{c m}^{\mathbf{2}} \\
\mathbf{n = 2 4}\end{array}$ & $\begin{array}{c}\mathbf{1 0 J} / \mathbf{c m}^{\mathbf{2}} \\
\mathbf{n = 2 4}\end{array}$ \\
$\mathbf{0 h}$ & $2,963(0,462)$ & $2,986(0,458)$ & $2,963(0,463)$ & $2,963(0,463)$ \\
$\mathbf{4 h}$ & $2,990(0,581)$ & $2,906(0,467)$ & $2,881(0,493)$ & $2,837(0,442)$ \\
$\mathbf{2 4 h}$ & $4,578(0,790)$ & $4,382(0,551)$ & $4,266(0,724)$ & $4,145(0,733)$ \\
$\mathbf{4 8 h}$ & $4,141(0,627)$ & $4,177(0,473)$ & $4,330(0,450)$ & $4,246(0,331)$ \\
\hline
\end{tabular}

Source: Authors. 
Table 2 - Average and standard deviation of the colony-forming units x $10^{8}$ of Lactobacillus reuteri in the control and irradiated groups at $660 \mathrm{~nm}$ wavelength, in fluences 1,5 and $10 \mathrm{~J} / \mathrm{cm}^{2}$

\begin{tabular}{|ccccc|}
\hline & $\begin{array}{c}\text { Control } \\
\mathbf{n = 2 3}\end{array}$ & $\begin{array}{c}\mathbf{1 J} / \mathbf{c m}^{\mathbf{2}} \\
\mathbf{n = 2 4}\end{array}$ & $\begin{array}{c}\mathbf{5 J} / \mathbf{c m}^{\mathbf{2}} \\
\mathbf{n = 2 3}\end{array}$ & $\begin{array}{c}\mathbf{1 0 J} / \mathbf{c m}^{\mathbf{2}} \\
\mathbf{n = 2 3}\end{array}$ \\
$\mathbf{0 h}$ & $3,093(0,518)$ & $3,116(0,519)$ & $3,095(0,520)$ & $3,093(0,518)$ \\
$\mathbf{4 h}$ & $4,536(1,165)$ & $4,328(0,903)$ & $4,357(0,890)$ & $4,897(1,085)$ \\
$\mathbf{2 4 h}$ & $17,257(2,754)$ & $17,245(2,515)$ & $17,181(1,595)$ & $18,189(1,718)$ \\
$\mathbf{4 8 h}$ & $14,307(3,709)$ & $14,633(3,047)$ & $16,114(2,576)$ & $15,754(2,230)$ \\
\hline
\end{tabular}

Source: Authors.

The growth of Escherichia coli was stimulated (Table 3) when we compared the $1 \mathrm{~J} / \mathrm{cm}^{2}$ group to the Control group, with statistical significance.

Table 3 - Average and standard deviation of colony-forming units x $10^{8}$ of Escherichia coli in the control and irradiated groups at $660 \mathrm{~nm}$ wavelength, in fluences 1,5 and $10 \mathrm{~J} / \mathrm{cm}^{2}$

\begin{tabular}{|ccccc|}
\hline & $\begin{array}{c}\text { Control } \\
\mathbf{n = 2 3}\end{array}$ & $\begin{array}{c}\mathbf{1 J} / \mathbf{c m}^{2} \\
\mathbf{n = 2 4}\end{array}$ & $\begin{array}{c}\mathbf{5 J} / \mathbf{c m}^{2} \\
\mathbf{n = 2 4}\end{array}$ & $\begin{array}{c}\mathbf{1 0 J} / \mathbf{c m}^{\mathbf{2}} \\
\mathbf{n = 2 3}\end{array}$ \\
$\mathbf{0 h}$ & $1,108(0,014)$ & $1,108(0,014)$ & $1,108(0,014)$ & $1,108(0,014)$ \\
$\mathbf{4 h}$ & $9,513(2,008)$ & $9,950(0,930)$ & $9,751(1,579)$ & $9,589(2,250)$ \\
$\mathbf{2 4 h}$ & $16,652(2,079)$ & $18,119(1,954)$ & $18,006(1,724)$ & $17,871(1,457)$ \\
$\mathbf{4 8 h}$ & $18,307(1,860)$ & $19,023(1,963)$ & $18,632(1,982)$ & $18,840(1,176)$ \\
\hline
\end{tabular}

Source: Authors.

The growth of Staphylococcus aureus did not undergo biostimulation (Table 4) in any of the fluences.

Table 4 - Average and standard deviation of the colony-forming units x $10^{8}$ (CFU) of Staphylococcus aureus in the control and irradiated groups at $660 \mathrm{~nm}$ wavelength, in fluences 1,5 and $10 \mathrm{~J} / \mathrm{cm}^{2}$

\begin{tabular}{|ccccc|}
\hline & $\begin{array}{c}\text { Controle } \\
\mathbf{n = 2 2}\end{array}$ & $\begin{array}{c}\mathbf{1 J} / \mathbf{c m}^{2} \\
\mathbf{n = 2 4}\end{array}$ & $\begin{array}{c}\mathbf{5 J} / \mathbf{c m}^{\mathbf{2}} \\
\mathbf{n = 2 3}\end{array}$ & $\begin{array}{c}\mathbf{1 0 J} / \mathbf{c m}^{\mathbf{2}} \\
\mathbf{n = 2 3}\end{array}$ \\
$\mathbf{0 h}$ & $1,137(0,049)$ & $1,137(0,049)$ & $1,137(0,049)$ & $1,137(0,049)$ \\
$\mathbf{4 h}$ & $6,420(1,382)$ & $5,916(1,526)$ & $6,100(1,540)$ & $5,976(1,071)$ \\
$\mathbf{2 4 h}$ & $15,189(1,260)$ & $15,265(2,471)$ & $15,748(1,935)$ & $15,160(2,608)$ \\
$\mathbf{4 8 h}$ & $16,286(2,730)$ & $16,682(3,712)$ & $15,871(3,097)$ & $15,664(3,111)$ \\
\hline
\end{tabular}

Source: Authors.

\section{Discussion}

Necrotizing Enterocolitis (NEC) is the leading cause of death from gastrointestinal diseases in neonates and is characterized by the development of diffuse intestinal necrosis in preterm infants subjected to stress. Still, it is the leading cause of intestinal failure in premature infants, which leads to Short Bowel Syndrome. The high incidence of NEC, and the 
lack of effective treatment strategies suggest that new approaches to the treatment of the disease are needed (Hackam et al., 2005). It is in this context that the possibility of using photobiomodulation as a therapeutic modality arises.

Current treatment for NEC involves antibiotics, fasting bowel rest, total parenteral nutrition, and surgical resection or peritoneal drainage when indicated. Each of these modalities is used to prevent the patient's septic condition from getting worse. However, none of these modalities effectively deals with the biological process involved in ECN. This may explain why the ECN mortality rate has changed so little over the past 40 years (Hackam et al., 2005; Hackam \& Caplan, 2018).

Possible new treatment fronts would neutralize the intestinal nitric oxide levels, minimizing the enterocytes' apoptosis, and restoring the epithelial restitution and proliferation. Photobiomodulation has already proven effective in this function, protecting cells against NO-induced apoptosis (Hackam et al., 2005; Farivar et al., 2014; Rizzi et al., 2018). Besides, therapeutic agents that act on RhoA-GTPase in the intestine, or restore basal sodium-proton exchange in the enterocyte, could mitigate endotoxins' effects on the intestinal barrier function. Photobiomodulation proved to be effective in activating RhoAGTPase, stimulating corneal epithelial cells (Hackam et al., 2005; Rhee et al., 2017).

The fact that enterocytes exposed to bacterial endotoxins express high levels of cyclooxygenase-2 leads us to an intriguing possibility that agents that modify COX-2 activity, or its expression may reduce the extent and severity of NEC in these patients. Tatmatsu-Rocha et al. (2018) showed in their work that the use of photobiomodulation in skin lesions of diabetic rats decreases the expression of COX-2. Interestingly, in this work, that comparing irradiation with Laser and LED, the latter showed better results in inhibiting the expression of COX-2 (Hackam et al., 2005; Tatmatsu-Rocha et al., 2018 ).

The choice of parameters used for irradiation was based on previous data from the literature, showing promising results in endothelial cells and fibroblasts in the red wavelength (Moore et al., 2005). Wavelengths of 500-700 nm are effective on more superficial tissues, while wavelengths of 800 to $1000 \mathrm{~nm}$ are indicated for deeper tissues (Kuffler, 2016). For the treatment of abdominal pathologies in newborns, wavelengths in the red band are sufficient. Another aspect is the behavior of different wavelengths in bacteria. While infrared irradiation alters bacteria's growth rate, in some cases stimulating them, irradiation in the red band has little effect on bacterial growth (Liebert et al., 2019; Nussbaum et al., 2002).

Regarding the choice of bacteria, Escherichia coli and Staphylococcus aureus are among the bacteria most commonly associated with NEC, one of which is Gram-negative and the other Gram-positive, allowing the study of the response of different bacterial types to the same treatment with photobiomodulation. Still, Lactobacilli are found in breast milk and the newborn's flora, but when supplemented with probiotic pills, they can lead to sepsis, showing that their increase during photobiomodulation would also be harmful (Hunter et al., 2008).

We observed in previous studies that very high fluences inhibit bacterial growth. Despite the positive result for pathogenic bacteria, irradiation would probably inhibit the growth of commensal bacteria (Sousa et al., 2016; Barboza et al., 2015).

The growth of $L$. acidophillus was slower compared to the growth of L. reuteri. Ribeiro in 2012 showed that the LA14 strain has a slower growth when compared to other strains of Lactobacillus spp (Ribeiro et al., 2012). Our study demonstrated that there is no influence of photobiomodulation on the growth of Lactobacillus. In 2020, Nemeth et al (2020) showed a decrease in the number of CFU of Lactobacillus irradiated with LEDs at wavelengths 625, 660, and $850 \mathrm{~nm}$ and an energy density of $16 \mathrm{~mW} / \mathrm{cm}^{2}$. The difference found can be explained by the fact that the salivary glands were irradiated by the extra-oral route (Nemeth et al., 2020).

In our study, in $E$. coli bacteria, irradiation with fluency of $1 \mathrm{~J} / \mathrm{cm}^{2}$ stimulated bacterial growth in relation to the Control group. In the other fluences, growth was stimulated, but without statistical significance. Nussbaum in 2002 showed no general effect on the growth of $E$. coli after irradiation with wavelengths $630,660,810$, and $905 \mathrm{~nm}$. The most significant inhibition occurred with $630 \mathrm{~nm}$ irradiation at a radiant exposure of $1 \mathrm{~J} / \mathrm{cm}^{2}$ (Nussbaum et al., 2002). Sousa in 2016 showed 
that $E$. coli had similar growth inhibition at a wavelength of $830 \mathrm{~nm}$ at fluencies of 3, 6, 12, and $24 \mathrm{~J} / \mathrm{cm}^{2}$. At 660 and $904 \mathrm{~nm}$ wavelengths, growth inhibition was observed only at 12 and $18 \mathrm{~J} / \mathrm{cm}^{2}$ fluences, respectively (Sousa et al., 2016).

In our study at $660 \mathrm{~nm} 0.025 \mathrm{~W} / \mathrm{cm}^{2}$, at doses of 5 and $10 \mathrm{~J} / \mathrm{cm}^{2}$, there was a decrease in the growth of $S$. aureus, but without statistical significance. Ranjbar \& Takhtfooladi (2016), in his in vivo study using photobiomodulation at parameters $685 \mathrm{~nm}$ InGaAlP $15 \mathrm{~mW}, 3 \mathrm{~J} / \mathrm{cm}^{2}$, obtained inhibition of the bacterial growth of $S$. aureus (Ranjbar \& Takhtfooladi, 2016). Sousa in 2012 showed that the infrared spectrum was more effective when compared to red, mainly for $904 \mathrm{~nm}$, since $660 \mathrm{~nm}$ did not promote global inhibition (Sousa et al., 2012).

The results obtained were optimistic. If there is no significant change in the intestinal flora, the potential for using photobiomodulation in intestinal pathologies, including necrotizing enterocolitis, begins to appear promising. The use of the $660 \mathrm{~nm}$ wavelength in the fluences of $5 \mathrm{~J} / \mathrm{cm}^{2}$ and $10 \mathrm{~J} / \mathrm{cm}^{2}$ in pathogenic bacteria did not lead to a significant change in the speed of growth, as well as in Lactobacillus.

\section{Conclusion}

Cultures of bacteria Lactobacillus acidophillus, L. reuteri, S. aureus irradiated at a wavelength of $660 \mathrm{~nm}$ and a power of $0.025 \mathrm{~W} / \mathrm{cm}^{2}$, in doses of 1,5 , and $10 \mathrm{~J} / \mathrm{cm}^{2}$ did not undergo biostimulation. E. coli growth was stimulated when we compared the $1 \mathrm{~J} / \mathrm{cm}^{2}$ group to the Control group, with statistical significance $(\mathrm{p}<0.005)$. In the other fluencies, there was no biostimulation. The use of the $660 \mathrm{~nm}$ wavelength in the fluences of $5 \mathrm{~J} / \mathrm{cm}^{2}$ and $10 \mathrm{~J} / \mathrm{cm}^{2}$ in pathogenic bacteria did not lead to a significant change in the speed of growth, as well as in Lactobacillus.

The results obtained were optimistic. If there is no significant change in the intestinal flora, the potential for using photobiomodulation in intestinal pathologies, including necrotizing enterocolitis, begins to appear promising.

\section{Acknowledgments}

This study was financially supported by grant of São Paulo Research Foundation FAPESP (2016/17984-1 and 2013/20054-8).

\section{References}

Aacos, M. L., Essa F., \& Diaz T. E., (2004). Criopreservacion de aislados nativos de la bacteria ruminal Fibrobacter succinogenes. Revista Corpoica 5, 60-63.

Barboza, L. L., Campos, V. M. A., Magalhaes, L. A. G., Paoli F., \& Fonseca A. S., (2015). Low-intensity red and infrared laser effects at high fluentes on Escherichia coli cultures. Braz. J. Med. Biol. Res. 48(10), 945-952.

Desmet, K. D., Paz, D. A., Corry, J. J., Eells, J. T., Wong-Riley, M. T., Henry, M. M., Buchmann, E. V., Connelly, M. P., Dovi, J. V., Liang, H. L., Henshel, D. S., Yeager, R. L., Millsap, D. S., Lim, J., Gould, L. J., Das, R., Jett, M., Hodgson, B. D., Margolis, D., \& Whelan, H. T., (2006). Clinical and experimental applications of NIR-LED photobiomodulation. Photomed. Laser Surg. 24(2), 121-128

Farivar, S., Malekshahabi, T., \& Shiari, R., (2014). Biological Effects of Low Level Laser Therapy. Journal of Lasers in Medical Sciences 5, 58-62.

Hackam, D., \& Caplan, M., (2018). Necrotizing enterocolitis: Pathophysiology from a historical context. Seminars in Pediatric Surgery 27, 11-18.

Hackam, D. J., Upperman, J. S., Grishin, A., \& Ford, H. R., (2005). Disordered enterocyte signaling and intestinal barrier dysfunction in the pathogenesis of necrotizing enterocolitis. Seminars in Pediatric Surgery 14, 49-57.

Hamblin, M. R., (2017). Mechanisms and applications of the anti-inflammatory effects of photobiomodulation. AIMS Biophys. 3, 337-361.

Hunter, C. J., Upperman, J. S., Ford, H. R., \& Camerini, V., (2008). Understanding the Susceptibility of the Premature Infant to Necrotizing Enterocolitis (NEC). Pediatric Research 63, 117-123.

Kuffler, D. P., (2016). Photobiomodulation in promoting wound healing: a review. Regen. Med. 11, 107-122.

Liebert, A., Bicknell, B., Johnstone, D. M., Gordon, L. C., Kiat, H., \& Hamblin, M. R., (2019). "Photobiomics": Can Light, Including Photobiomodulation, Alter the Microbiome? Photobiomodulation, Photomedicine, and Laser Surgey 37(11), 681-693. 
Research, Society and Development, v. 10, n. 8, e56810817103, 2021

(CC BY 4.0) | ISSN 2525-3409 | DOI: http://dx.doi.org/10.33448/rsd-v10i7.17103

Moore, P., Ridgway, T. D., Higbee, R. G., Howard, E. W., \& Lucroy, M. D., (2005). Effect of wavelength on low-intensity laser irradiation-stimulated cell proliferation in vitro. Lasers in Surgery and Medicine 36, 8-12.

Nemeth, L., Groseli, M., Golez, A., Arhar, A., Frangez, I., \& Cankar, K., (2020). The impact of photobiomodulation of major salivary glands on caries risk. Lasers in Medical Science 35, 193-203.

Nussbaum, E. L., Lilge, L., \& Mazzulli, T., (2002). Effects of 630, 660, 810, and 905nm Laser Irradiation Delivering Radiant Exposure of 1-50 J/cm² on Three Species of Bacteria in Vitro. Journal of Clinical Laser Medicine and Surgery 20, 325-333.

Nussbaum, E. L., Lilge, L., \& Mazzulli, T., (2003). Effects of Low-Level Laser Therapy (LLLT) of $810 \mathrm{~nm}$ upon in vivo Growth of Bacteria: Relevance of Irradiance and Radiant Exposure. Journal of Clinical Laser Medicine \& Surgery 21, 283-290.

Obladen, M., (2009). Necrotizing Enterocolitis - 150 Years of Fruitless Search for the Cause. Neonatology 96, 203-210.

Pereira, A. S., Shitsuka, D. M., Parreira, F. J., \& Shitsuka, R. (2018). Metodologia da pesquisa científica. Ed. Santa Maria, RS: UFSM, NTE.

Ranjbar, R., Takhtfooladi, M. A., (2016). The effects of photobiomodulation therapy on Staphylococcus aureus infected surgical wounds in diabetic rats. A microbiological, histopathological, and biomechanical study. Acta Cirúrgica Brasileira 31(8), 498-504.

Rhee, Y., Cho, K. J., Ahn, J., \& Chung, P., (2017). Effect of Photobiomodulation on Wound Healing of the Corneal Epithelium through Rho-GTPase. Med Laser 6, 67-76.

Ribeiro, K. M., Pereira, L. C., Souza, C. H. B., \& Saad, S. M.I., (2012). Comportamento de cepas distintas de Lactobacillus acidophilus em queijo petit-suisse. Archivos Latinoamericanos de Nutrición 62, 347-354.

Rizzi, M., Migliario, M., Tonello, S., Rocchetti, V., \& Reno, F., (2018). Photobiomodulation induces in vitro re-epithelialization via nitric oxide production. Lasers in Medical Science 33, 1003-1008.

Samuels, N., van de Graaf, R. A., Jonge, R. C. J., Reiss, I. K. M., \& Vermeulen, M. J., (2017). Risk factors for necrotizing enterocolitis in neonates: a systematic review of prognostic studies. BMC Pediatrics 17, 01-09.

Sousa, N. T. A., Gomes, R. C., Santos, M. F., Brandino, H. E., Martinez, R., \& Guirro, R. R. J., (2016). Red and infrared laser therapy inhibits in vitro growth of major bacterial species that commonly colonize skin ulcers. Lasers Med Sci 31, 549-556.

Sousa, N. T. A., Guirro, R. R. J., Santana, H. F., \& Silva, C. C. M., (2012). In Vitro Analysis of Bacterial Morphology by Atomic Force Microscopy of Low Level Laser Therapy 660, 830 and $904 \mathrm{~nm}$. Photomedicine and Laser Surgery 30(5), 1-5.

Sueh, W., Caplan, M. S., Xiao-Wu, Q., Xiao-Di, T., Plaen, I. G., \& Gonzalez-Crussi, F., (2002). Neonatal Necrotizing Enterocolitis: Clinical Considerations and Pathogenetic Concepts. Pediatric and Developmental Pathology 6, 6-23.

Tatmatsu-Rocha, J. C., Tim, C. R., Avo, L., Bernardes-Filho, R., Brassolatti, P., Kido, H. L., Hamblin, M. R., \& Parizotto, N. A., (2018). Mitochondrial dynamics (fission and fusion) and collagen production in a rat T model of diabetic wound healing treated by photobiomodulation: comparison of $904 \mathrm{~nm}$ laser and $850 \mathrm{~nm}$ light-emitting diode (LED). Journal of Photochemistry \& Photobiology, B: Biology 187, 41-47. 